\title{
Entretenimento, Sociabilidade e Consumo nas Redes Sociais: cativando o consumidor-fã ${ }^{1}$
}

\section{Entertainment, sociability and consumption in social networks: Fostering the fan-consumer}

\author{
Gisela G.S. Castro²
}

\begin{abstract}
RESUMO
Entende-se o consumo como instância privilegiada para pensar a experiência contemporânea no contexto da crescente penetração do mercado nas esferas mais diversificadas de nossas vidas, notadamente no âmbito da subjetividade. A parceria entre as culturas midiática e do consumo enseja formatos e modelos inovadores, como a comunicação interpessoal de massa. As lógicas do entretenimento, da sociabilidade e dos negócios se entrecruzam neste tipo de interação característico da cultura digital atual. De modo lúdico, compartilha-se um volume sem precedentes de conteúdo nas redes sociais digitais, que congregam pessoas e negócios ao redor do mundo. Para expandir e cativar a clientela, são oferecidas as mais diversas experiências, notadamente aquelas que se servem das linguagens e lógicas do entretenimento para atrair a sempre fugaz atenção do público em nosso hipersaturado ecossistema comunicacional. A ambição de envolver o consumidor como parceiro e fã de determinada marca, produto ou serviço está presente com maior ou menor grau de transparência na comunicação mercadológica, tornando indispensável problematizar a participação dita espontânea nas redes sociais.
\end{abstract}

Palavras-chave: comunicação e consumo, redes sociais, consumidor-fã, subjetividade.

\begin{abstract}
Consumption is considered a privileged stance that enables us to reflect upon our contemporary experience within the context of the ever-growing penetration of the market in the most diverse spheres of our lives, especially in the realm of subjectivity. The close connection between media and consumption cultures gives rise to innovative formats and genres such as mass self-communication. The logics of entertainment, sociability and business intertwine in this type of interaction which is typical of today's digital culture. In a fun way, an unprecedented volume of content is shared on digital social networks which congregate people and businesses around the world. In order to expand and captivate one's customer base, the most diverse types of experience are offered, notably those which make use of the languages and logics of entertainment in order to capture the public's ever evading attention in our hyper-saturated communicational ecosystem. The ambition to engage the consumer as a partner and fan of a given brand, product or service is present with varying degrees of transparency in market communication, rendering it indispensible to question the so called spontaneous participation in social networks.
\end{abstract}

Key words: communication and consumption, social networks, fan-consumer, subjectivity.

${ }^{1}$ Uma versão deste trabalho foi apresentada no I Encontro de Grupos de Pesquisa em Comunicação e Consumo (I COMUNICON), no GT Comunicação, consumo, entretenimento e cultura digital, em outubro de 2011.

${ }^{2}$ Docente e Pesquisadora do Programa de Mestrado em Comunicação e Práticas de Consumo da Escola Superior de Propaganda e Marketing (PPGCOM-ESPM ). Rua Dr. Álvaro Alvim, 123, Vila Mariana, 04018-010, São Paulo, SP, Brasil. E-mail: castro.gisela@gmail.com 


\section{Introdução}

O consumo pode ser entendido como instância privilegiada para pensar a experiência contemporânea no contexto da crescente penetração do mercado nas esferas mais diversificadas de nossas vidas, notadamente no âmbito da subjetividade. Sendo assim, o principal objetivo deste trabalho é discutir a apropriação estratégica dos sites e redes digitais como YouTube, Facebook, Orkut e Twitter para a produção de um tipo de ator social aqui denominado como consumidor-fã. A intenção é examinar a constituição social e mercadológica desse ator característico da atual fase do capitalismo, denominada por Castells (2003) de "capitalismo informacional".

Observa-se, especialmente nesta última década, que a parceria entre mídia e consumo tem dado origem a formatos e modelos inovadores de comunicação entre marcas e seu público, especialmente no contexto da cultura digital. Num ambiente cada vez mais saturado de mensagens publicitárias dentro e fora de seus espaços mais tradicionais, o desafio para os profissionais de mercado está em procurar oferecer conteúdo relevante que seja capaz de capturar a atenção sempre fugaz do cliente em potencial. Ao longo da discussão serão analisadas campanhas especialmente produzidas nos últimos anos para que circulem nas redes sociais, caracterizando o chamado marketing viral.

De modo colaborativo e lúdico, compartilha-se um volume sem precedentes de conteúdo nas redes informacionais que congregam pessoas e negócios ao redor do mundo. A ambição de envolver o consumidor como parceiro e fã de determinada marca, produto ou serviço está presente com maior ou menor grau de transparência na comunicação mercadológica atual, tornando indispensável problematizar a participação dita "espontânea" nas redes sociais. Para expandir e cativar a clientela são oferecidas as mais diversas experiências relacionadas às marcas, notadamente aquelas que se servem das linguagens e lógicas do entretenimento. Estimula-se o chamado consumo de experiências, tão importante ou mais hoje em dia do que outras modalidades mais habituais de consumo. Entendo ser relevante examinar com rigor que tipo de experiência está sendo compreendida nessa modalidade de oferta.
Ao longo dessa argumentação serão examinados exemplos de sucessos e insucessos no sempre delicado relacionamento com o consumidor-fã. Desse modo, espero poder contribuir para a compreensão do problemático, complexo e multifacetado processo de mercadorização ${ }^{3}$ das subjetividades no contemporâneo.

\section{Nota sobre o ecossistema comunicacional contemporâneo}

Para começar essa discussão, é fundamental localizar a cibercultura ${ }^{4}$ no próprio ecossistema comunicacional contemporâneo. Parece problemático ainda insistir em dicotomias como real/virtual, analógico/digital, material/ informacional, humano/pós-humano. Designar o tecnológico como instância artificial e separada da experiência humana, a qual só seria autêntica se fosse "natural", nunca soou tão inapropriado e démodée. Indispensável nesse debate, Latour $(1995,2005)$ nos ensina a compreender a codependência entre humanos e não humanos. Destaca-se ainda a evidente importância dos mais diversos tipos de mediação na vida cotidiana, tornando de vez sem sentido a pretensa separação entre natureza e cultura. Dentre os diversos tipos de mediação, a forte presença dos meios de comunicação faz com que muitos estudiosos designem nossa sociedade como "midiática" (Moraes, 2006). A comunicação em rede, também denominada pós-massiva (Lévy e Lemos, 2010), contribui para complexificar ainda mais o ecossistema comunicacional no qual hoje convivem a comunicação em rede e a comunicação de massa (Moraes, 2010).

A utilização do prefixo ciber para denominar o espaço informacional (ciberespaço) não implica na conotação de que se trata de um universo à parte 5 . Nosso espaço urbano, cada vez mais permeado por redes wireless, ou sem fio, testemunha a crescente hibridização que favorece a conectividade, a mobilidade e a ubiquidade características dos tempos atuais ${ }^{6}$. Em uma obra que tem justamente esses três termos como subtítulo, Lucia Santa-

\footnotetext{
${ }^{3}$ A utilização do neologismo se justifica ao designar a notável penetração das lógicas de mercado nas mais diversas esferas da vida atual.

${ }^{4}$ Recomendo as reflexões de Erick Felinto $(2010,2007)$ ao tratar da cibercultura em termos epistemológicos.

${ }^{5}$ Para uma interessante leitura sobre o ciberespaço, ver Lucrécia Ferrara (2010).

${ }^{6}$ Uma análise rigorosa dessa questão pode ser encontrada em André Lemos (2010).
} 
ella (2010b, p. 81) constata que "a partir do final dos anos 1980, o termo "hibridismo" tornou-se palavra-chave para caracterizar as sociedades contemporâneas, especialmente as latino-americanas e, nelas, especialmente a brasileira". $\mathrm{Na}$ observação da autora, os termos hibridismo, hibridização ou mesmo hibridação têm sido utilizados para fazer referência tanto à convergência midiática propiciada pelo tratamento digital de todo o tipo de informação quanto ao entrecruzamento de linguagens nos contextos hipermídia.

Em capítulo dedicado especialmente a esmiuçar os múltiplos sentidos do conceito de hibridismo, Santaella (2010a) chama a atenção para o papel fundamental desempenhado por aquele que aciona e interage com as múltiplas interfaces, "cooperando na sua realização" (2010a, p. 93). Trata-se do receptor ou leitor imersivo, o interator "sem o qual a hipermídia não se realiza” (2010a p. 92).

Também Martín-Barbero nos convida (2008, p. 24) a "pensar a técnica como ambiente tecnológico e ecossistema comunicativo" de modo a sermos capazes de refletir sobre os múltiplos cruzamentos entre subjetividades e tecnicidades sensoriais e cognitivas propiciadas pela imbricação entre nossos sentidos, cérebro e fluxos informacionais. Ao entender que os jovens atuais seriam sujeitos "intima e estruturalmente mediados por suas interações pela e com a tecnologia" (2008, p. 22), o autor localiza uma dupla valência nas tecnologias comunicacionais: se por um lado elas podem propiciar novas experiências de subjetivação como, por exemplo, apresentar-se numa rede social como se fosse um(a) personagem com faixa etária, estado civil, profissão, características físicas distintas - por outro lado corre-se o risco de que essa expressividade se torne apenas funcional na medida em que seria manipulável pelas forças do mercado.

É bastante evidente a nossa crescente configuração como usuários e audiências dos meios de comunicação. Conforme argumenta Manuel Castells (2009), a proliferação das redes telemáticas informacionais enseja um novo modelo de comunicação que combina de modo paradoxal características da comunicação interpessoal com a comunicação massiva. $\mathrm{O}$ autor denomina essa nova modalidade de "comunicação interpessoal de massa" (mass self communication). A liberação do polo emissor celebrada nos primórdios da consolidação da cibercultura como forma cultural torna-se problemática em meio à significativa presença de sofisticados programas de software e de estratégias midiáticas como o buzz marketing e o marketing viral que modulam a comunicação entre pares de modo nem sempre evidente.

Além disso, nos bastidores das redes info-comunicacionais o monitoramento das interações online alimenta gigantescos bancos de dados nos quais peritos trabalham para extrair algoritmos que traduzam perfis identitários e padrões de conduta articuláveis em nichos de consumo. Em trabalho anterior, abordei a construção social e mercadológica do internauta como inter-agente ou interator nos circuitos e redes digitais. Como tenho observado ao longo de pesquisas, a consolidação da integração multimidiática decorrente da convergência digital e das transformações culturais em curso enseja a figura do internauta como interator e favorece novos modos de sociabilidade e hábitos de consumo. Outros trabalhos anteriores trataram da reorganização da indústria fonográfica frente à crescente preferência por música em arquivo digital ${ }^{7}$ e o compartilhamento gratuito online, por exemplo. Nessa trajetória pessoal de pesquisa destaca-se o interesse permanente pela articulação entre mídia e consumo na produção de modelos de subjetividade compatíveis com as demandas de mercado, bem como a emergência de formas de resistência aos padrões hegemônicos.

\section{Vendem-se estilos de vida e modos de ser}

Conforme ensina Suely Rolnik, "não há subjetividade sem uma cartografia cultural que the sirva de guia; e, reciprocamente, não há cultura sem um certo modo de subjetivação que funcione segundo seu perfil. A rigor, é impossível dissociar essas paisagens" (1997, p. 29). Comentando sobre os efeitos psicoculturais da globalização econômica, a autora constata a produção de "identidades prêt-à-porter" (1997, p. 22) para consumo das subjetividades chamadas a funcionar nas sempre cambiantes órbitas de mercado.

Em competente estudo sobre as estratégias de legitimação do capital no Brasil das últimas três décadas, $\mathrm{Ma}$ ria Eduarda Mota Rocha analisa a responsabilidade social e a qualidade de vida como valores que passam a informar o discurso publicitário nas últimas décadas do século XX. Coerentes com o ideário neoliberal vigente, tais narrativas passaram a ter como intuito "construir a boa vontade da

${ }^{7} \mathrm{O}$ CD deixa de ser o principal produto que sustenta o mercado fonográfico quando proliferam os tocadores digitais portáteis capazes de estocar enormes quantidades de músicas acessáveis na Internet. 
opinião pública - e converter parte desta em consumidores efetivos de produtos e serviços" por meio da imagem da vida plena (Mota Rocha, 2010, p. 13, grifos no original).

Lazzarato e Negri analisam as formas de vida e a produção de subjetividade em nossos dias, salientando que "o capitalismo não é mais o capitalismo da produção, mas do produto. $\mathrm{O}$ marketing não é mais somente uma técnica de venda, mas um dispositivo de constituição das relações sociais, de informações, de valores para o mercado" (2001, p. 64). $\mathrm{Na}$ visão dos pesquisadores italianos, que corrobora a argumentação aqui proposta, a lógica mercantil pretende reger o social, o político e a comunicação, investindo nos processos individuais e coletivos de subjetivação.

Em obra de referência sobre o assunto na América Latina, Néstor Garcia Canclini demonstra a tese de que "o consumo serve para pensar" (1996, p. 51) e criar cidadania. Argumentando em favor de uma contextualização multidisciplinar dos processos comunicacionais, que leve em conta os estudos do consumo, o Canclini afirma que "a comunicação não é eficaz se não inclui também interações de colaboração e transação entre uns e outros"(1996, p. 52). Em trabalho mais recente, o autor tece considerações sobre o aspecto hibrido da experiência do internauta, definindo-o como "agente multimídia que lê, ouve e combina materiais diversos, procedentes da leitura e dos espetáculos" (Garcia Canclini, 2008, p. 22). Nessa reflexão, o estudioso avalia a redução da influência da escola em nossos dias, perdendo espaço tanto para a mídia de massa quanto para as redes de comunicação digital e eletrônica. Para Garcia Canclini, "num mundo cada vez mais interligado e regido por intercâmbios de ordem mercantil", convertem-se "todos os cenários em lugares de compra e venda” (2008, p. 23). Nesse contexto, "os jovens adquirem nas telas extracurriculares uma formação mais ampla em que conhecimento e entretenimento se combinam" (2008, p. 23). Entretanto, o autor lucidamente reconhece não ser nada fácil "passar da conectividade indistinta ao pensamento crítico" (2008, p. 24).

A capacidade de conjugar de modo efetivo o fascínio do mundo dos espetáculos e a interatividade das redes de comunicação instantânea e ubíqua está na base de estratégias como o buzz e o viral, pedras de toque da estreita imbricação que se configura nas redes sociais digitais entre negócios, comunicação e sociabilidade. Também as narrativas transmidiáticas, aquelas cujo universo ficcional se desdobra em múltiplas plataformas, têm sido amplamente exploradas pela indústria do entretenimento e também pelo marketing, contribuindo para configurar o internauta como receptor privilegiado de transmedia storytelling.

\section{Entretenimento, sociabilidade e consumo}

Marcas como Apple, Coca-Cola, Harley-Davidson e Montblanc, para citar apenas algumas em ordem alfabética, são bem conhecidas por congregar e incentivar a fidelidade de legiões de clientes na forma de admiradores e fãs. Mais do que a mera promoção de produtos ou serviços, percebe-se nesses casos um bem sucedido esforço em construir modos de ser que gerem identificação, atraindo o consumidor para o universo simbólico da marca. Analisando-se esse tipo de estratégia, percebe-se o fomento à consolidação de um tipo de agente social ao qual interessa o envolvimento mais pessoal e direto com o intangível da marca em questão. Trata-se do apelo ao capital emocional destacado por autores como Jenkins $(2009,2006)$. Do cliente ao fã; do comprador ao colecionador aficionado; do consumidor ao colaborador e principal divulgador, a cultura digital coloca à disposição do mercado toda uma gama de processos interativos que tanto podem ajudar a consolidar o prestigio e a reputação de determinada marca, quanto colaborar para o seu ocaso se o esforço for mal sucedido.

Tradicionalmente, a comunicação mercadológica serviu-se do modelo baseado na interrupção da programação dos meios de comunicação (rádio e televisão, por exemplo) para veiculação de mensagens comerciais. No entanto, programas financiados ou patrocinados por anunciantes também façam parte do chamado mix de comunicação expressão do universo do marketing que designa o conjunto de ferramentas a serem utilizadas em um dado plano de mídia - muito antes desta expressão entrar em vigor. Dentre outros fatores, a proliferação de canais e a concorrência da internet contribuíram para desestabilizar o modelo tradicional invasivo - que, no entanto, não desapareceu - tornando necessário também investir na sedução do consumidor por outros meios, como no caso da inserção de conteúdo mercadológico no próprio roteiro dos produtos culturais. A consolidação da mass media entertainment industry ${ }^{8} \mathrm{e}$

\footnotetext{
${ }^{8}$ Referência aos grandes conglomerados de mídia e entretenimento que operam em escala internacional unindo interesses comerciais e culturais.
} 
as possibilidades abertas pela apropriação mercadológica das redes sociais digitais contribuem para desestabilizar as já tênues fronteiras entre negócios e conteúdo cultural.

Experimenta-se com formatos híbridos como o advertainment, dentre os quais os já clássicos filmes de curta duração feitos por grandes nomes do cinema para os carros da BMW'. Exibidos em duas temporadas no site da empresa por meio de softwar ${ }^{10}$ especialmente desenvolvido para esse fim, os BMW Films geraram enorme sucesso de público e crítica, dando início ao fenômeno da viralização de conteúdo online. Os filmes - que hoje fazem parte da coleção permanente do MOMA em Nova Iorque - motivaram a produção de diversos subprodutos, tais como paródias, ou spoofs, no sempre renovado processo de metalinguagem e intertextualidade que caracteriza a produção midiática em nossos dias.

\section{Life's for Sharing}

Analisando as transformações na comunicação publicitária no contexto do que denomina "civilização do nicho", o publicitário Nizan Guanaes afirma que “o monólogo está virando diálogo. A propaganda está virando conteúdo e o conteúdo está virando propaganda" (Guanaes, 2012). Na sua especulação sobre o futuro da propaganda, o estrelado e controvertido profissional ensina que "o digital não é um pedaço, é o todo, o grande hub" (Guanaes, 2012). Sendo um hub um concentrador do tráfego numa determinada rede, essa concepção da arena digital justifica os investimentos no desenvolvimento de novos formatos no campo do marketing e da publicidade.
Um exemplo relevante de marketing viral é a campanha Life's for Sharing, desenvolvida para a T-Mobile, fabricante alemã e operadora de telefonia móvel. Concebida no inovador formato das flashmobs ${ }^{11}$, a campanha teve como mote a produção de espetáculos meticulosamente coreografados para parecerem espontaneamente deflagrados em meio a situações cotidianas nos grandes centros urbanos. O filme intitulado The T-Mobile Dance foi lançado em janeiro de $2009 \mathrm{em}$ canal especialmente criado pela empresa no YouTube, gerando um número recorde de visualizações. Um teaser $^{12}$ da campanha e o making of mostrando os bastidores da filmagem também foram disponibilizados, contribuindo para a consolidação do $b u z z^{13}$ que estimula a disseminação viral do conteúdo.

Poucos meses depois dessa ação, uma chamada veiculada na televisão - e também no YouTube - convidava o público para participar da próxima etapa da campanha. Aludindo ao sucesso da ação no metrô de Londres, o vídeo informava dia, hora e local em que iria ocorrer a próxima ação no centro de Londres. Destaca-se a utilização estratégica da intertextualidade nessa modalidade de convocação. O Trafalgar Square Sing-along reuniu milhares de pessoas ${ }^{14}$ - incluindo algumas celebridades - cantando em conjunto um antigo sucesso dos Beatles. Dentre outros fatores, causou impacto a gigantesca tela de LED que foi especialmente desenvolvida para projetar em praça pública a letra de Hey Jude, em meio a flagrantes da multidão que cantava. O comercial resultante foi veiculado pela televisão em horário nobre. Versões ampliadas foram posteriormente disponibilizadas no canal da empresa no YouTube.

O filme seguinte teve como locação um portão de desembarque do movimentado aeroporto de $\mathrm{He}-$ athrow, em Londres. Welcome Back envolveu um coral de 300 vozes cantando e simulando a orquestração de

\footnotetext{
${ }^{9}$ Esta campanha pioneira envolveu profissionais do porte de Ridley e Tony Scott, Ang Lee, Guy Ritchie, Clive Owen e Madonna numa série de oito filmes de curta-metragem tendo os carros da marca como protagonistas. The Hire Film Series teve em sua primeira temporada os títulos Ambush, Chosen, The Follow, Star, Power Keg. A segunda temporada, que também contou com o lançamento dos filmes em DVD exclusivos que podiam ser encomendados no site da empresa, foi composta por Hostage, Ticker e Beat the Devil. O fim da série foi anunciado em 2005. Desde então diversas campanhas semelhantes têm sido criadas, evidenciando a boa aceitação do formato por parte de anunciantes, agências e público em geral.

${ }^{10} \mathrm{O}$ mesmo software que possibilitava a visualização e o download dos filmes no site da empresa trazia fotos e detalhes técnicos dos carros utilizados na série, demonstrando aproveitamento inteligente das especificidades da plataforma hipermídia

${ }^{11}$ Aglomerações instantâneas em locais públicos como ruas, praças, estações de trem ou metrô com o intuito de realizar determinadas ações (geralmente de caráter inusitado) previamente combinadas. Originalmente tratava-se de um modo de intervenção artística e ou política no espaço urbano, tendo como base as redes móveis de comunicação sem fio.

${ }^{12}$ Do inglês tease (provocar), os teasers são trailers enigmáticos veiculados antes do lançamento de determinadas campanhas, destinados a atiçar a curiosidade do público e gerar certo frisson antecipatório.

${ }_{13}^{13}$ Bochicho ou muvuca, numa tradução livre da expressão em inglês, já consagrada no meio do marketing para designar o equivalente digital do tradicional boca-a-boca.

${ }^{14}$ Segundo dados oficiais da campanha, 13,500 pessoas lotaram a famosa praça londrina em 30 de abril de 2009.
} 
uma calorosa e inesperada cerimônia de boas vindas que congregou passageiros, tripulação e demais presentes no saguão do aeroporto.

$\mathrm{O}$ uso da metalinguagem foi também muito oportunamente explorado pela mesma campanha por ocasião da comoção causada pelo casamento entre o príncipe William e Kate Middleton. A versão caricata do casamento real veiculada pela T-Mobile teve como inspiração um fenômeno de viralização no YouTube, que mostrava a inusitada coreografia que marcou a entrada de noivos, sacerdote, pais e padrinhos numa cerimônia religiosa nos $\mathrm{EUA}^{15}$. Aludindo à tradição das paródias que tomam como referência outros produtos midiáticos, a campanha inovou ao abrir mão da característica mistura entre simulação de espontaneidade e espaço público presente nos filmes anteriores.

Ninguém gosta de surpresas desagradáveis (Nobody Likes Nasty Surprises) teve como meta divulgar um plano que permite ao consumidor determinar os minutos e o volume de dados que deseja contratar em sua assinatura mensal com a empresa. Um correlato brasileiro desse tipo de campanha foi veiculado há algum tempo por uma fabricante de automóveis. $\mathrm{O}$ caráter nonsense do apelo publicitário e a alusão explícita à intenção de viralização do comercial nas redes sociais contribuíram para tornar $A$ maldição dos pôneis um case de referência no meio publicitário.

®Keep Walking Brazil, campanha desenvolvida para uma fabricante de bebidas, tem como público-alvo o internauta brasileiro, notório entusiasta das redes sociais digitais. Aludindo ao slogan da marca em questão, o filme utiliza tratamento imagético impactante para transformar o morro do Pão de Açúcar, cartão postal da cidade do Rio de Janeiro e uma das vistas mais difundidas do Brasil no exterior, em um gigante que se levanta e se põe a caminhar. Outro exemplo mais recente de estratégia viral é My Time is Now, campanha internacional lançada por uma marca de artigos esportivos que se serve de celebridades do mundo do futebol e de recursos interativos para repercutir junto aos usuários de internet ao redor do mundo.
Evidentemente, a imprevisibilidade faz sempre parte da regra do jogo na comunicação publicitária. Por mais que se parta de uma ideia criativa e que ela seja desenvolvida em esquema profissional, com todo o apuro na produção, nunca se pode prever em que medida o fenômeno da viralização irá ocorrer numa campanha desse tipo, pois são muitos os imponderáveis e os riscos aos quais se está sujeito.

O CONAR (Conselho Nacional de Autorregulamentação), que define a si próprio como uma organização não-governamental que visa impedir que a publicidade enganosa ou abusiva cause constrangimento ao consumidor ou a empresas, foi acionado por consumidores insatisfeitos com a associação entre personagens infantis (os pequenos pôneis de brinquedo ${ }^{16}$ ) e a figura do mal ${ }^{17}$. Embora os conselheiros tenham decidido por unanimidade arquivar as denúncias, o caso coloca em evidência a linha tênue que separa a ironia do sarcasmo e da ofensa, bem como a complexidade do processo de recepção na comunicação ${ }^{18}$.

É importante ressaltar nessa parte da argumentação a enorme força simbólica do compartilhamento de elementos sígnicos capazes de conjugar diferentes pessoas numa mesma "comunidade", "tribo" ou "geração"19. Desde o Napster - pioneiro aplicativo que, praticamente sem concorrência, deflagrou o compartilhamento de música online no final dos anos 1990 -, o envolvimento nesse tipo de prática congrega pessoas, promove a participação em redes e estimula a colaboração espontânea entre pares. É justamente esse o ponto trabalhado pelas campanhas virais. Uma dos elementos de sucesso do primeiro sistema de compartilhamento musical online era a maneira pessoal e direta pela qual Shawn Fanning (o criador do Napster) finalizava suas mensagens aos associados, sempre utilizando o slogan "Thanks for sharing" ${ }^{20}$. Ao estimular a manutenção de laços afetivos que consolidem o pertencimento a grupos afinitários, estimula-se o hábito do compartilhamento de todo tipo de conteúdo nas redes sociais - incluindo mensagens audiovisuais como as mencionadas acima. Do ponto de vista de seus produtores, pretende-se que seja uma forma atraente e não invasiva de fazer-se presente: tornando relevante e interessante a mensagem de deter-

\footnotetext{
${ }^{15}$ O Casamento de Jill e Kevin (The Jill and Kevin Wedding Dance Entrance), ocorrido em julho de 2009.

${ }^{16} \mathrm{Da}$ série de desenhos animados Meu querido pônei, lançada juntamente com uma linha de brinquedo na década de 1980 (mostrados no comercial). A série deu origem a um filme de longa metragem de mesmo nome que é até hoje lembrado com carinho pelos que eram crianças naquela época e hoje têm entre 30 e 40 anos (identificando-se com o público-alvo desse lançamento da Nissan). ${ }^{17}$ Alusão à galhofa da "maldição do pônei" proposta pela campanha que zomba da concorrência.

${ }^{18}$ A esse respeito, recomendo a leitura atenta de Baccega (2009).

${ }^{19}$ Propositalmente, não entro aqui no mérito de cada uma dessas noções, sempre problemáticas, tomando-as como equivalentes.

${ }^{20}$ Em tradução livre: "Obrigado por compartilhar”.
} 
minada marca, de modo a não somente atrair a atenção, como, sobretudo, cativar o consumidor como fã. Por meio das redes de compartilhamento de conteúdo, este atua como parceiro ao endossar a marca junto às suas redes de contato.

\section{O consumidor-fã nas redes sociais: risco ou oportunidade?}

Evidentemente, nem tudo é colaboração, elogio ou endosso nas mensagens sobre marcas, serviços e produtos que circulam nas redes sociais. $\mathrm{O}$ exemplo do consumidor brasileiro que recorreu à Web para veicular sua insatisfação com determinada marca de eletrodomésticos ${ }^{21}$ gerou imediata comoção e solidariedade. $\mathrm{O}$ elevado número de acessos ao que parece ser um vídeo caseiro postado no YouTube pelo revoltado comprador de uma geladeira que apresentava defeito de fabricação, assim como a grande quantidade de mensagens de apoio que circularam nas redes sociais, testemunham a expressiva receptividade do caso junto à opinião pública. A intensa mobilização dos internautas obrigou a empresa a se desculpar publicamente de modo a preservar sua boa reputação no Brasil, país que, como se sabe, reúne um volume expressivo de usuários de redes sociais na internet.

Há alguns anos um caso desse tipo obteve ampla repercussão no YouTube, em grande medida devido ao modo criativo e atraente por meio do qual certo músico que teve seu violão avariado durante um voo comercial difundiu o seu protesto. Depois de reclamar sem sucesso com a companhia aérea, decidiu postar na web um vídeo no qual ele e sua banda aparecem cantando uma música em estilo country, especialmente composta para narrar o incidente de modo zombeteiro. Dois dias depois, outro vídeo foi lançado, dessa vez contendo um depoimento do instrumentista agradecendo a onda de solidariedade vinda dos quatro cantos do planeta. A jocosa trilogia gerou novas fontes de renda para o autor ${ }^{22}$, além de diversos tipos de material correlato, incluindo um vídeo de resposta do fabricante do violão que aproveitou para reforçar a presença e a credibilidade da marca. $\mathrm{O}$ caso United Breaks Guitars foi matéria da prestigiosa Harvard Business Review, sendo ainda considerado emblemático no campo do marketing.

A capacidade de lidar de modo eficiente com o consumidor-internauta que expressa publicamente sua opinião sobre marcas, produtos e serviços já há muito tem sido considerada atributo indispensável no mundo dos negócios. Apropriações por parte do público geram produtos como as fan fics, narrativas que se desenvolvem dentro de universos ficcionais compartilhados por fãs e apreciadores ${ }^{23}$, além de paródias ou spoofs nem sempre bem vistos sob a ótica do mundo empresarial. $\mathrm{O}$ monitoramento de redes sociais faz parte de estratégias corporativas nos mais diversos segmentos de mercado. É preciso saber estar presente na rede, assim como também interagir a tempo e de forma adequada com a opinião pública na arena digital. São muitas as armadilhas que podem denunciar despreparo ou inaptidão, fragilizando a imagem pessoal ou corporativa.

Por outro lado, também não são infrequentes os casos em que a participação nas redes e a colaboração espontânea entre pares são moduladas por ardilosas estratégias de mercado. Um exemplo marcante ocorreu por ocasião de campanha da Ambev para o Guaraná Antártica lançada por meio de mensagem viral falsa ${ }^{24}$ de repúdio ao perigo causado ao ecossistema na Amazônia por suposta empresa norte-americana, durante visita do então presidente Bush ao país. O caso repercutiu na web chegando à cena política com veemente pronunciamento em plenário no Senado nacional (cf. Delgado, 2007).

Concluindo esta argumentação sobre a relação com usuários de novos meios com suas possibilidades de emissão, produção e compartilhamento de conteúdo, chamo a atenção para a necessidade de discutirmos a diversidade de estratégias que se valem das lógicas

\footnotetext{
${ }^{21}$ Depois de três meses sem geladeira, um consumidor indignado teria decidido protestar contra a fabricante por meio de um vídeo caseiro de protesto postado no YouTube. A ação levou a Brastemp aos Trending Topics mundiais do Twitter, atingindo o primeiro lugar no Brasil. Ciente do protagonismo brasileiro entre os usuários do microblog, não há como menosprezar o impacto desta iniciativa. ${ }^{22}$ Que hoje capitaliza a notoriedade obtida tendo lançado um livro sobre a sua experiência e oferecendo-se como palestrante em eventos corporativos, para os quais se dispõe a compor canções por encomenda. Vale conferir os links corporativos do músico Dave Carroll, apresentados nas referências.

${ }^{23}$ Ver interessante texto de Simone Pereira de Sá sobre essa temática em Sá e Enne (2005).

${ }^{24}$ Chama-se hoax, termo que pode ser traduzido como embuste ou farsa, a esse tipo de mensagem falsa que circula na internet.
} 
do entretenimento no contexto das redes digitais de comunicação, sociabilidade e consumo. Implícita nessas estratégias, está em jogo a formação de certo tipo de subjetividade que mescla características distintas, visando constituir e interpelar o consumidor-fã nas redes sociais.

\section{Referências}

BACCEGA,M.A. 2009. Inter-relações comunicação e consumo na trama cultural: o papel do sujeito ativo. In: G.G.S.CASTRO; M.P.TONDATO, Caleidoscópio midiático: o consumo pelo prisma da comunicação. São Paulo, ESPM, p. 12-30.

CASTELLS, M. 2009. Communication power. Oxford/New York, Oxford University Press, 571 p.

CASTELLS, M. 2003. A galáxia da internet: reflexóes sobre a internet, os negócios e a sociedade. Rio de Janeiro, Jorge Zahar, $326 \mathrm{p}$. DELGADO,M.2007. Senador propõe audiência com diretores de empresa que é parte de jogo virtual. FOLHA ONLINE, ed. 30 de março. Disponível em http://www1.folha.uol.com. br/folha/brasil/ult96u90804.shtml. Acesso em agosto de 2012. FELINTO, E. 2010. Think different: estilos de vida digitais e a cibercultura como expressão cultural. In: E.TRIVINHO; A.P. REIS (orgs.), A cibercultura em transformação: poder, liberdade e sociabilidade em tempos de compartilhamento, nomadismo e mutação direitos. São Paulo, ABCiber/Itaú Cultural, p. 39-47.

FELINTO, E. 2007. Sem mapas para esses territórios: a cibercultura como campo de conhecimento. In: J. FREIRE FILHO; M. HERSCHMANN (orgs.), Novos rumos da cultura da mídia: indústrias, produtos, audiências. Rio de Janeiro, Mauad X, p. 45-58. FERRARA, L.D'A. 2010. Ciberespaço: conceito à procura de um nome. In: E. TRIVINHO; Â.P. REIS (orgs.), A cibercultura em transformação: poder, liberdade e sociabilidade em tempos de compartilhamento, nomadismo e mutação direitos. São Paulo, ABCiber/ Itaú Cultural, p. 60-69.

GARCIA CANCLINI, N.1996. Consumidores e cidadãos: conflitos multiculturais da globalização. Rio de Janeiro, Ed.UFRJ, $228 \mathrm{p}$. GARCIA CANCLINI, N. 2008. Leitores, espectadores e internautas. S. Paulo, Iluminuras, 96 p.

GUANAES, N.2012. O futuro da propaganda. Folha de S. Paulo, 29 de maio. Caderno Mercado, p. B8.

JENKINS, H. 2009. Cultura da convergência. São Paulo, Aleph, $428 \mathrm{p}$.

JENKINS, H. 2006. Fans, bloggers, and gamers: exploring participatory culture. New York, New York University Press, 279 p. KLEIN, N. 2010. Ed. comemorativa dos 10 anos de No Logo. Londres, Fourth Estate, 502 p.
LATOUR, B. 1994. Jamais fomos modernos: ensaio de antropologia simétrica. Rio de Janeiro, Ed. 34, 152 p.

LATOUR, B. 2005. Reassembling the social: an introduction to actor-network-theory. Oxford, N. York, Oxford University Press, $301 \mathrm{p}$.

LAZZARATTO,M.; NEGRI,A. 2001. Trabalho imaterial:formas de vida e produção de subjetividade. Rio de Janeiro, DP\&A, 108 p. LEMOS, A. 2010. Mobile communication and new sense of places: a critique of spatialization in cyberculture. In: E.TRIVINHO; A. P. REIS (orgs.), A cibercultura em transformação:poder, liberdade e sociabilidade em tempos de compartilhamento, nomadismo e mutação direitos. São Paulo, ABCiber/Itaú Cultural, p.97-112. LÉVY, P.; LEMOS, A. 2010. O futuro da internet: em direção a uma ciberdemocracia planetária. São Paulo, Paulus, 264 p.

MARTÍN-BARBERO, J. 2008. A mudança na percepção da juventude: sociabilidades, tecnicidades e subjetividades entre os jovens. In: S.H.S. BORELLI; J. FREIRE FILHO (orgs.), Culturas juvenis no século XXI. São Paulo, EDUC, p. 9-32.

MORAES, D. (org.).2010. Mutações do visível: da comunicação de massa à comunicação em rede. Rio de Janeiro, Pão e Rosas, 235 p. MORAES, D. (org.).2006. Sociedade midiatizada. Rio de Janeiro, Mauad, 246 p.

MOTA ROCHA,M.E.2010. A nova retórica do capital: a publicidade brasileira em tempos neoliberais. São Paulo, EDUSP, 266 p. ROLNIK, S. 1997. Toxicômanos de identidade: subjetividade em tempo de globalização. In: D. LINS (org.), Cultura e subjetividade: saberes nômades. Campinas, Papirus, p. 19-24.

SÁ, S.P.; ENNE, A.L. (orgs.). 2005. Prazeres digitais: computador, entretenimento e sociabilidade. Rio de Janeiro, E-Papers, 148 p. SANTAELLA, L. 2010a. Ecologia pluralista das mídias locativas. In: E. TRIVINHO; A. P. REIS (orgs.), A cibercultura em transformação: poder, liberdade e sociabilidade em tempos de compartilhamento, nomadismo e mutação direitos. São Paulo, ABCiber/ Itaú Cultural, p. 90-96.

SANTAELLA, L. 2010b. Ecologia pluralista da comunicação: conectividade, mobilidade, ubiqüidade. São Paulo, Paulus, 394 p.

Submetido em: 07/02/2012 Aceito em: 05/06/2012 